\title{
Ambrosia Beetle (Coleoptera: Scolytidae) Species, Flight, and Attack on Living Eastern Cottonwood Trees
}

\author{
D. R. COYLE ${ }^{1}$ D. C. BOOTH ${ }^{2}$ AND M. S. WALLACE ${ }^{3}$ \\ USDA Forest Service, Southern Research Station, New Ellenton, SC 29809
}

\begin{abstract}
J. Econ. Entomol. 98(6): 2049-2057 (2005)
ABSTRACT In spring 2002, ambrosia beetles (Coleoptera: Scolytidae) infested an intensively managed 22-ha tree plantation on the upper coastal plain of South Carolina. Nearly 3,500 scolytids representing 28 species were captured in ethanol-baited traps from 18 June 2002 to 18 April 2004. More than $88 \%$ of total captures were exotic species. Five species [Dryoxylon onoharaensum (Murayama), Euwallacea validus (Eichhoff), Pseudopityophthorus minutissimus (Zimmermann), Xyleborus atratus Eichhoff, and Xyleborus impressus Eichhoff]) were collected in South Carolina for the first time. Of four tree species in the plantation, eastern cottonwood, Populus deltoides Bartram, was the only one attacked, with nearly $40 \%$ of the trees sustaining ambrosia beetle damage. Clone ST66 sustained more damage than clone S7C15. ST66 trees receiving fertilization were attacked more frequently than trees receiving irrigation, irrigation + fertilization, or controls, although the number of S7C15 trees attacked did not differ among treatments. The study location is near major shipping ports; our results demonstrate the necessity for intensive monitoring programs to determine the arrival, spread, ecology, and impact of exotic scolytids.
\end{abstract}

KEY WORDS ethanol, fertilization, invasive species, Populus deltoides, Xyleborini

NeARLY 50\% OF EXTINCT or imperiled species in the United States were caused, in part, by invasive species (Wilcove et al. 1998). Pimentel et al. (2000) suggest that invasive species cost the U.S. economy $\$ 138$ billion annually. There are $>400$ invasive insect species in U.S. forests, encompassing a wide range of feeding guilds (Mattson et al. 1994). Bark and ambrosia beetles (Coleoptera: Scolytidae) can be particularly hard to detect because of their cryptic lifestyle and the difficulty in effectively monitoring their populations in remote areas. Several invasive scolytids are of concern because of their unknown damage potential (Atkinson et al. 1988b, Mizell et al. 1994, Bright and Rabaglia 1999, Vandenberg et al. 2000, Haack 2001, Schiefer and Bright 2004). In the absence of effective monitoring, exotic species may persist undetected for many years before discovery (Liebhold et al. 1995, Humble 2003).

Ambrosia beetles, with the exception of a short flight period, spend their entire life within a woody

The U.S. Government has the right to retain a nonexclusive, royaltyfree license in and to any copyright covering this paper. Mention of a commercial or proprietary product does not constitute endorsement or recommendation by the USDA Forest Service, Bartlett Tree Research Laboratories, or East Stroudsburg University for its use.

${ }^{1}$ Current address: Department of Entomology, 345 Russell Labs, University of Wisconsin, Madison, WI 53706 (e-mail: dcoyle@ entomology.wisc.edu).

${ }^{2}$ Bartlett Tree Research Laboratories, 13768 Hamilton Rd., Charlotte, NC 28278

${ }^{3}$ Department of Biological Sciences, 200 Prospect St., East Stroudsburg University, East Stroudsburg, PA 18301 stem (Rudinsky 1962). Native ambrosia beetles generally attack weakened or stressed trees; however, healthy trees are frequently attacked by exotic species (Rudinsky 1962, Wood 1982b, Kühnholz et al. 2001). Damage to sawn lumber can be particularly severe near logging operations, where felled logs serve as an attractant to ambrosia beetles (McLean 1985). Ambrosia beetle infestation of conifer pulp logs resulted in losses of $>\$ 77 / \mathrm{m}^{3}$ of $\log$ and reduced value on high-grade logs by $57 \%$ (Orbay et al. 1994). In the southeastern United States, healthy peach trees as well as nursery trees and shrubs are at risk to boring and fungal inoculation, particularly by the exotic ambrosia beetle Xylosandrus crassiusculus (Motschulsky) (Kovach and Gorsuch 1985, 1988; Mizell et al. 1994).

Intensively managed forest plantations (Stanturf et al. 2001) may have production rates high enough to potentially offset the global increase in demand for wood and wood products (Fenning and Gershenzon 2002, Stanton et al. 2002). Populus species and hybrids are especially suited to intensive management because of their rapid growth, ease of propagation, and desirable wood qualities (Dickmann and Stuart 1983). Unfortunately, plantation monocultures make them prone to a suite of pests and diseases (Coyle et al. 2005).

In spring 2002, an ambrosia beetle infestation occurred on apparently healthy eastern cottonwood, Populus deltoides Bartram, in an intensively managed plantation in South Carolina. This infestation provided 
Table 1. Average monthly weather from 18 June 2002 to 18 April 2004 at the Savannah River Site, Aiken, SC

\begin{tabular}{lrccr}
\hline \hline Mo & $\begin{array}{c}\text { Temp } \\
\left({ }^{\circ} \mathrm{C}\right)\end{array}$ & $\begin{array}{c}\text { Relative } \\
\text { humidity } \\
(\%)\end{array}$ & $\begin{array}{c}\text { Wind } \\
\text { speed } \\
\left(\mathrm{km} \mathrm{h}^{-1}\right)\end{array}$ & $\begin{array}{c}\text { Rainfall } \\
(\mathrm{cm})\end{array}$ \\
\hline Jan. & 5.4 & 72.2 & 2.4 & 8.8 \\
Feb. & 7.4 & 79.0 & 3.4 & 20.6 \\
Mar. & 13.9 & 76.4 & 3.8 & 23.5 \\
April & 15.5 & 75.6 & 3.2 & 38.1 \\
May & 20.9 & 85.3 & 2.9 & 15.2 \\
June & 23.5 & 84.7 & 2.7 & 13.2 \\
July & 25.7 & 83.2 & 2.3 & 25.9 \\
Aug. & 25.1 & 84.4 & 2.3 & 4.6 \\
Sept. & 22.5 & 84.9 & 2.6 & 5.8 \\
Oct. & 17.6 & 88.2 & 1.9 & 7.7 \\
Nov. & 12.2 & 84.1 & 2.4 & 3.3 \\
Dec. & 5.9 & 79.2 & 2.5 & 13.6 \\
\hline
\end{tabular}

an opportunity to document the composition and seasonal flight patterns of the local scolytid fauna, critical information for the detection and management of exotic species (Simberloff et al. 2005). We hypothesized that the majority of captured beetles would be exotic species (Kovach and Gorsuch 1985) because ports in South Carolina provide opportunities for exotic scolytids to establish after being imported in ballast or other wood products (Haack 2001).

We also hypothesized ambrosia beetle flight patterns would peak in spring and late summer, as documented previously (Roling and Kearby 1975, Turnbow and Franklin 1980, Atkinson et al. 1988a, Weber and McPherson 1991). Finally, because the incidence and severity of pest damage can differ among $P$. deltoides clones and resource amendment treatments (Coyle 2002, Herms 2002, Huberty and Denno 2004, Coyle et al. 2005), we hypothesized that the incidence of ambrosia beetle attack would differ between two $P$. deltoides clones and would be highest in trees receiving irrigation and fertilization amendments.

\section{Materials and Methods}

Experimental Setting. The study took place at the U.S. Department of Energy Savannah River Site, a National Environmental Research Park, near Aiken, SC $\left(33^{\circ} 23^{\prime} \mathrm{N}, 81^{\circ} 40^{\prime} \mathrm{W}\right)$. A detailed description of the plant material, silvicultural treatments, and experimental design can be found in Coleman et al. (2004) and Coyle and Coleman (2005). Before logging in 1999, vegetation included 14-yr-old pulp quality loblolly pine, Pinus taeda L., and 38-yr-old pole timber quality longleaf pine, Pinus palustris Miller, with an oak, Quercus spp., understory; this flora surrounded the site on three sides, with a small town to the north. After logging in 1999, all soil and debris were homogenized to a depth of $30 \mathrm{~cm}$. Temperature, relative humidity, wind speed, and rainfall data (Table 1) were recorded continuously during the study period by a weather station (Campbell Scientific, Inc., Logan UT) installed in a cleared area $50 \mathrm{~m}$ west of the site.

In spring 2000, eastern cottonwood; American sycamore, Platanus occidentalis L.; sweetgum, Liquidambar styraciflua L.; and loblolly pine were planted. Two eastern cottonwood clones (ST66 of Issaquena County, Mississippi, and S7C15 of Brazos County, Texas) were planted as unrooted hardwood cuttings stored at $3^{\circ} \mathrm{C}$ and soaked in water for $48 \mathrm{~h}$ before planting.

Tree genotypes were arranged in a randomized complete block. Each 0.22-ha plot contained 14 rows of 21 trees (total of 294 trees), planted at 2.5 by $3-\mathrm{m}$ spacing. Each of three blocks contained one plot per treatment for each genotype, grouped together to minimize within-site variation. Treatments consisted of control (C), irrigation (I), fertilization (F), and irrigation + fertilization (IF). We applied irrigation treatments $\left(0.5 \mathrm{~mm} \mathrm{~d}^{-1}\right)$ via an automated system to both I and IF treatments. Liquid fertilizer was applied through the automated system to $\mathrm{F}$ and IF treatments at 40,80 , and $120 \mathrm{~kg} \mathrm{~N} \mathrm{ha}^{-1} \mathrm{yr}^{-1}$ in 2000,2001 , and 2002 (and thereafter), respectively, to correspond with the increasing demand of growing trees.

Weed control treatments included an oxyflourfen (Goal 2XL, Rohm and Haas Co., Philadelphia, PA) application before budbreak, and glyphosate (Roundup Pro, Monsanto Corp., St. Louis, MO) applications as needed throughout the growing season. Dicofol (Kelthane, Rohm and Haas Co.) was applied to control the mite Tetra lobulifera Kiefer (Coyle 2002). All pesticides were applied as needed according to label directions.

Beetle Trapping and Identification. Four 12-unit Lindgren multiple funnel traps (Lindgren 1983) were installed in June 2002 on the plantation perimeter with the bottom of the traps $1 \mathrm{~m}$ above ground. Traps were baited with ethanol released at $275 \mathrm{mg} \mathrm{d}^{-1}$ (L2-2041/ 500 UHR ethanol lure; Phero Tech, Inc., Delta, British Columbia, Canada) and checked at 7-14-d sampling periods from 18 June 2002 to 18 April 2004. To kill and preserve captured insects, sample cups were filled with a 50:50 mixture of water and propylene glycol. Weeds around the traps were controlled mechanically and were not allowed to obscure the trap. With the exception of two genera, all Scolytidae were identified to species (Wood 1982a, Wood and Bright 1992, Bright and Skidmore 1997). Voucher specimens were deposited in the Clemson University Entomology Museum and the personal collections of R. J. Rabaglia (Maryland Department of Agriculture) and D.R.C.

Beetle Attack. Two P. deltoides trees (clone S7C15) were destructively sampled in May 2002. Both had black discoloration on the lower bole, an indication of beetle attack; sap exuded from beetle entrance holes was the primary cause of discoloration. Trees were sampled from border rows in the $\mathrm{F}$ and IF treatments. All beetles within the basal $1 \mathrm{~m}$ of stem were excised and identified to species.

From 18 to 21 June 2002, we recorded the incidence (presence, 1; absence, 0 ) of beetle attack on 360 trees in each P. deltoides clone. For each P. deltoides clone, three rows of 10 trees, bordered by at least two rows of buffer trees, were monitored in each plot $(n=90$ trees treatment ${ }^{-1}$ ) by using bole discoloration as a presence or absence indicator. Any tree having bole 
Table 2. Total number of Scolytidae captured using ethanol-baited lures from 18 June 2002 to 18 April 2004 at the Savannah River Site, Aiken, SC

\begin{tabular}{|c|c|c|c|c|c|c|c|}
\hline Exotic & Tribe & Species & 2002 & 2003 & 2004 & Total & $\%$ of total \\
\hline Yes & Xyleborini & Ambrosiodmus rubricollis (Eichhoff) & 23 & 33 & 1 & 57 & 1.63 \\
\hline No & Xyleborini & Ambrosiodmus tachygraphus (Zimmermann) & 0 & 5 & 3 & 8 & 0.23 \\
\hline No & Bothrosternini & Cnesinus strigicollis LeConte & 0 & 0 & 1 & 1 & 0.03 \\
\hline Yes & Dryocoetini & Dryoxylon onoharaensum (Murayama) & 42 & 145 & 7 & 194 & 5.55 \\
\hline Yes & Xyleborini & Euwallacea validus (Eichhoff) & 0 & 1 & 0 & 1 & 0.03 \\
\hline No & Corthylini & Gnathotrichus materiarius (Fitch) & 0 & 1 & 0 & 1 & 0.03 \\
\hline No & Hylesinini & Hylastes tenuis Eichhoff & 1 & 2 & 1 & 4 & 0.11 \\
\hline No & Cryphalini & Hypothenemus spp. & 72 & 146 & 34 & 252 & 7.21 \\
\hline No & Ipini & Ips avulsus (Eichhoff) & 3 & 2 & 0 & 5 & 0.14 \\
\hline No & Ipini & Ips calligraphus (Germar) & 0 & 1 & 0 & 1 & 0.03 \\
\hline No & Micracini & Micracisella nanula (LeConte) & 0 & 2 & 0 & 2 & 0.06 \\
\hline No & Corthylini & Monarthrum fasciatum (Say) & 0 & 10 & 2 & 12 & 0.34 \\
\hline No & Corthylini & Monarthrum mali (Fitch) & 0 & 5 & 6 & 11 & 0.31 \\
\hline Yes & Ipini & Orthotomicus caelatus (Eichhoff) & 1 & 0 & 3 & 4 & 0.11 \\
\hline No & Ipini & Pityogenes hopkinsi Swaine & 0 & 1 & 0 & 1 & 0.03 \\
\hline No & Corthylini & Pityophthorus spp. & 4 & 9 & 0 & 13 & 0.37 \\
\hline No & Corthylini & Pseudopityophthorus minutissimus (Zimmermann) & 2 & 0 & 0 & 2 & 0.06 \\
\hline No & Corthylini & Pseudopityophthorus pruinosus Eichhoff & 0 & 3 & 0 & 3 & 0.09 \\
\hline Yes & Xyleborini & Xyleborinus saxeseni (Ratzburg) & 674 & 1,426 & 150 & 2,250 & 64.38 \\
\hline No & Xyleborini & Xyleborus affinis Eichhoff & 1 & 6 & 0 & 7 & 0.20 \\
\hline Yes & Xyleborini & Xyleborus atratus Eichhoff & 0 & 21 & 33 & 54 & 1.55 \\
\hline Yes & Xyleborini & Xyleborus californicus Wood & 0 & 51 & 11 & 62 & 1.77 \\
\hline No & Xyleborini & Xyleborus ferrugineus (F.) & 7 & 10 & 0 & 17 & 0.49 \\
\hline No & Xyleborini & Xyleborus impressus Eichhoff & 18 & 36 & 0 & 54 & 1.55 \\
\hline No & Xyleborini & Xyleborus pubescens Zimmermann & 1 & 9 & 1 & 11 & 0.31 \\
\hline Yes & Xyleborini & Xylosandrus compactus (Eichhoff) & 0 & 2 & 0 & 2 & 0.06 \\
\hline Yes & Xyleborini & Xylosandrus crassiusculus (Motschulsky) & 35 & 348 & 82 & 465 & 13.30 \\
\hline \multirow[t]{2}{*}{ No } & Xyloterini & Xyloterinus politus (Say) & 0 & 0 & 1 & 1 & 0.03 \\
\hline & & Total & 884 & 2275 & 336 & 3,495 & \\
\hline
\end{tabular}

discoloration was considered attacked. Attacks were not found on sycamore, sweetgum, or loblolly pine.

Statistical Analyses. Scolytidae biodiversity, $H$, was calculated using the Shannon-Weiner diversity index (Shannon 1948, Zar 1999)

$$
H=\left[n \log n-\sum_{i=1}^{k}\left(f_{i} \log f_{i}\right)\right] / n
$$

where $n$ is total number of beetles captured, $k$ is total number of species (richness), and $f$ is number of beetles in species $i$.

Evenness, $J$, was calculated as the ratio of $H$ to $H_{\text {max }}$ ( $H_{\max }$ being the theoretical maximum possible diversity for a set of data with $k$ categories; Pielou 1966, Zar 1999), where $H_{\max }=\log k$.

$H$ and $J$ were calculated for beetles captured in this study and other southeastern United States studies (Turnbow and Franklin 1980, Atkinson et al. 1988a, Weber and McPherson 1991, Oliver and Mannion 2001, Grant et al. 2003) with which we compared our data.

To account for slight variations in our sampling periods and the occasional loss of a funnel trap because of wind, trap captures were standardized as number of beetles trap ${ }^{-1} \mathrm{~d}^{-1}$ over each sampling period. Attack incidence (the proportion of trees attacked) between $P$. deltoides clones was analyzed using Fisher's exact test for dichotomous data (Simple Interactive Statistical Analysis Software, Hilversum, The Netherlands). Mean separations among attack incidence in the four silvicultural treatments within clones were performed using the Tukey-type multiple comparison test among proportions (Zar 1999). In all cases, $\alpha=0.05$.

\section{Results}

Species Composition. We captured 3,495 scolytids, mostly tribe Xyleborini, over 94 wk (Table 2). Seven of the 28 species were captured every year. Nine exotic species made up $>88 \%$ of the total specimens collected. Xyleborinus saxeseni (Ratzburg) accounted for $>64 \%$ of total trap captures alone (Table 2). X. saxeseni, X. crassiusculus, and Hypothenemus spp. accounted for nearly $85 \%$ of all specimens collected. Twenty species were represented by $<20$ individuals (Table 2). Diversity was calculated as 0.59 , and evenness was 0.41 (Table 3). Dryoxylon onoharaensum (Murayama), Euwallacea validus (Eichhoff), Pseudopityophthorus minutissimus (Zimmermann), Xyleborus atratus Eichhoff, and Xyleborus impressus Eichhoff represented new records for South Carolina.

Flight Patterns. Beetle flight was fairly constant from late June through November 2002 (Fig. 1A). Noticeable decreases in flight occurred when temperatures or humidity were unusually high. The decreases in flight activity in mid-August and mid-September 2003 corresponded to mean temperatures $>28^{\circ} \mathrm{C}$ and relative humidity $>94 \%$, respectively. Activity ceased from late November 2002 until the end of January 2003 , when beetles occurred in very small numbers $\left(<0.04\right.$ beetles trap $\left.{ }^{-1} \mathrm{~d}^{-1}\right)$. Beginning in late February 2003 , flight activity began to increase steadily (Fig. 
Table 3. Number of Scolytidae captured and diversity indices compared with other published studies in the southeastern United States

\begin{tabular}{|c|c|c|c|c|c|c|}
\hline Species & $\mathrm{SC}^{a}$ & $\mathrm{FL}^{b}$ & $\mathrm{GA}^{c}$ & $\mathrm{NC}^{d}$ & $\mathrm{TN}^{e}$ & $\mathrm{TN}^{f}$ \\
\hline Ambrosiodmus devexulus (Wood) & & 16 & & & & \\
\hline Ambrosiodmus lecontii Hopkins & & 37 & & & & \\
\hline Ambrosiodmus obliquus (LeConte) & & & & & & 1 \\
\hline Ambrosiodmus rubricollis (Eichhoff) & 57 & & & & 82 & 1 \\
\hline Ambrosiodmus tachygraphus (Zimmermann) & 8 & 1 & 83 & 16 & 110 & 13 \\
\hline Carphoborus bifurcus (Eichhoff) & & 3 & & 1 & & \\
\hline Chramesus hicoriae LeConte & & & 1 & 1 & & \\
\hline Cnesinus strigicollis LeConte & 1 & 3 & 17 & & & \\
\hline Conophthorus resinosae Hopkins & & & & 68 & & \\
\hline Corthylus columbianus Hopkins & & & 26 & & 11 & \\
\hline Corthylus punctatissimus (Zimmermann) & & 3 & & & & \\
\hline Corthylus spinifer Schwartz & & 26 & & & & \\
\hline Cryptocarenus seriatus Eggers & & 31 & & & & \\
\hline Crypturgus alutaceus Schwartz & & 14 & 170 & & & \\
\hline Dendroctonus frontalis Zimmermann & & & 136 & & & \\
\hline Dendroctonus terebrans (Oliver) & & 3 & 3 & & & \\
\hline Dryocoetes autographus (Ratzburg) & & & 5 & & & \\
\hline Dryocoetes granicollis (LeConte) & & & & & & 2 \\
\hline Dryoxylon onoharaensum (Murayama) & 194 & & & & 16 & \\
\hline Euwallacea validus (Eichhoff) & 1 & & & & & \\
\hline Gnathotrichus materiarius (Fitch) & 1 & 4 & 53 & 1 & 1 & \\
\hline Hylastes porculus Erichson & & & 106 & 1 & & \\
\hline Hylastes salebrosus (Eichhoff) & & 2 & 38 & 1 & & \\
\hline Hylastes tenuis Eichhoff & 4 & 520 & 121 & 10 & & \\
\hline Hylesinus aculeatus Say & & & 4 & 5 & & \\
\hline Hylocurus torosus Wood & & & 1 & 1 & & \\
\hline Hylurgopinus rufipes (Eichhoff) & & & 2 & & & \\
\hline Hypothenemus californicus Hopkins & & & & 4 & & \\
\hline Hypothenemus crudiae (Panzer) & & & & 8 & & \\
\hline Hypothenemus dissimilis (Zimmermann) & & & 109 & 7 & & 4 \\
\hline Hypothenemus eruditus (Westwood) & & & 4 & 3 & & \\
\hline Hypothenemus interstitialis (Hopkins) & & & 6 & 3 & & \\
\hline Hypothenemus obscurus (Fabricius) & & & & 35 & & \\
\hline Hypothenemus sp. 1 & & & & & 10 & \\
\hline Hypothenemus sp. 2 & & & & & 5 & \\
\hline Hypothenemus sp. 3 & & & & & 2 & \\
\hline Hypothenemus spp. & 252 & 312 & & & & \\
\hline Ips avulsus (Eichhoff) & 5 & 227 & 20 & 13 & & 4 \\
\hline Ips calligraphus (Germar) & 1 & 91 & & & & \\
\hline Ips grandicollis (Eichhoff) & & 366 & 46 & 16 & & 6 \\
\hline Ips pini (Say) & & & & 20 & & \\
\hline Lymantor decipiens (LeConte) & & & & 1 & & \\
\hline Micracis swainei Blackman & & & & 1 & & \\
\hline Micracisella nanula (LeConte) & 2 & 7 & & & & \\
\hline Micracisella opacicollis LeConte & & & 68 & & & \\
\hline Monarthrum fasciatum (Say) & 12 & 1 & 669 & 31 & 600 & 6 \\
\hline Monarthrum mali (Fitch) & 11 & 25 & 280 & 104 & 278 & 3 \\
\hline Orthotomicus caelatus (Eichhoff) & 4 & 4 & 9 & 16 & & 9 \\
\hline Phloeosinus dentatus (Say) & & & 3 & & & \\
\hline Phloeotribus frontalis (Oliver) & & & 6 & 14 & & \\
\hline Phloeotribus liminaris (Harris) & & & 7 & 1 & & \\
\hline Pityoborus comatus (Zimmermann) & & 12 & 1 & & & \\
\hline Pityogenes hopkinsi Swaine & 1 & & & 69 & & \\
\hline Pityogenes meridianus Blackman & & & 1 & & & \\
\hline Pityogenes plagiatus (LeConte) & & & & 26 & & \\
\hline Pityophthorus annectans LeConte & & & 8 & & & \\
\hline Pityophthorus cariniceps LeConte & & & & 6 & & \\
\hline Pityophthorus confusus bellus Blackman & & & 9 & & & \\
\hline Pityophthorus consimilis LeConte & & & & 34 & & \\
\hline Pityophthorus crinalis (Blackman) & & & 16 & 7 & & \\
\hline Pityophthorus liquidambarus Blackman & & & & & 3 & \\
\hline Pityophthorus puberulus (LeConte) & & & & 3 & & \\
\hline Pityophthorus pulchellus Eichhoff & & & & 2 & & \\
\hline Pityophthorus pullus (Zimmermann) & & & & 4 & & \\
\hline Pityophthorus sp. 1 & & & & & 1 & \\
\hline Pityophthorus sp. 2 & & & & & 1 & \\
\hline Pityophthorus spp. & 13 & 538 & & 1 & & \\
\hline Pseudopityophthorus asperulus (LeConte) & & 3 & & 1 & & \\
\hline Pseudopityophthorus minutissimus (Zimmermann) & 2 & & 2 & 10 & & \\
\hline Pseudopityophthorus pruinosus Eichhoff & 3 & & 2 & 8 & & 1 \\
\hline Pseudopityophthorus pubescens Blackman & & & 2 & 3 & & \\
\hline Pseudothysanoes lecontei Blackman & & & & 7 & & \\
\hline
\end{tabular}


Table 3. Continued

\begin{tabular}{|c|c|c|c|c|c|c|}
\hline Species & $\mathrm{SC}^{a}$ & $\mathrm{FL}^{b}$ & $\mathrm{GA}^{c}$ & $\mathrm{NC}^{d}$ & $\mathrm{TN}^{e}$ & $\mathrm{TN}^{f}$ \\
\hline Scolytus multistriatus Marsh. & & & 14 & & & \\
\hline Scolytus quadrispinosus Say & & & & & & 3 \\
\hline Scolytus rugulosus (Muller) & & & & 2 & & \\
\hline Thysanoes fimbricornis LeConte & & & 1 & 3 & & \\
\hline Thysanoes pallens Wood & & & & 1 & & \\
\hline Trypodendron scabricollis (LeConte) & & & 1 & & & \\
\hline Xyleborinus gracilis (Eichhoff) & & & & 2 & & \\
\hline Xyleborinus saxeseni (Ratzburg) & 2,250 & 10,929 & 2,143 & 3,507 & 2,390 & 5 \\
\hline Xyleborus affinis Eichhoff & 7 & 786 & 15 & 11 & 2 & 15 \\
\hline Xyleborus atratus Eichhoff & 54 & & & & 136 & 8 \\
\hline Xyleborus californicus Wood & 62 & & & & 9 & \\
\hline Xyleborus celsus Eichhoff & & & 1 & 1 & & \\
\hline Xyleborus ferrugineus (Fabricius) & 17 & 192 & 8 & 93 & 8 & 22 \\
\hline Xyleborus impressus Eichhoff & 54 & & & & & \\
\hline Xyleborus intrusus Blandford & & & & 1 & & \\
\hline Xyleborus obliquus (LeConte) & & & & 2 & & \\
\hline Xyleborus pelliculosus Eichhoff & & & & & 197 & 2 \\
\hline Xyleborus planicollis Zimmermann & & & & 5 & & \\
\hline Xyleborus pubescens (Zimmermann) & 11 & 143 & 61 & 6 & & 20 \\
\hline Xyleborus sayi (Hopkins) & & & 221 & 1 & 14 & \\
\hline Xyleborus viduus Eichhoff & & & & 1 & & \\
\hline Xyleborus xylographus (Say) & & & & 126 & & \\
\hline Xylosandrus compactus (Eichhoff) & 2 & 13 & & & & \\
\hline Xylosandrus crassiusculus (Motschulsky) & 465 & & & & 848 & 1 \\
\hline Xylosandrus germanus Blandford & & & & 76 & 83 & \\
\hline Xyloterinus politus (Say) & 1 & & & 3 & 3 & 1 \\
\hline$H$ & 0.59 & 0.47 & 0.91 & 1.49 & 0.72 & 1.11 \\
\hline$H_{\max }$ & 1.45 & 1.46 & 1.64 & 1.76 & 1.36 & 1.28 \\
\hline$J$ & 0.41 & 0.32 & 0.55 & 0.85 & 0.53 & 0.87 \\
\hline
\end{tabular}

${ }^{a}$ Data from this study; conducted using Lindgren funnel traps with ethanol lures.

${ }^{b}$ Data from Atkinson et al. (1988a); conducted using both sticky and window traps with felled slash pine, Pinus elliottii Engelmann.

${ }^{c}$ Data from Turnbow and Franklin (1980); conducted using window traps with no lure.

${ }^{d}$ Data from Weber and McPherson (1991); conducted using window traps with no lure.

${ }^{e}$ Data from Oliver and Mannion (2001); conducted using Lindgren funnel traps with ethanol lures.

${ }^{f}$ Data from Grant et al. (2003); conducted using direct collections, sweep netting, beat-sheeting, deadwood dissection, light trapping, canopy fogging, malaise trapping, and pitfall trapping with no additional lures.

1A). A substantial rain $(6.9 \mathrm{~cm})$ on 20 March 2003 likely reduced trap catches just before their greatest levels ( 13 beetles trap ${ }^{-1} \mathrm{~d}^{-1}$ ) on 1 April 2003. Heavy rain fell during the first $2 \mathrm{wk}$ of April $2003(14.6 \mathrm{~cm})$, and again on 25 April $2003(40.9 \mathrm{~cm})$, decreasing trap captures a final time (Fig. 1A) before their natural decline. Flight activity remained consistent throughout the remainder of summer and fall, until ceasing completely in the beginning of December 2003 (Fig. 1A). Beetles first occurred in mid-March 2004, much later than in 2003, and exhibited consistent flight activity until we stopped trapping in April 2004.

Flight patterns of X. saxeseni (Fig. 1B) and $H y$ pothenemus spp. (Fig. 1D) indicated that these species were present at all times except during the winter. $X$. crassiusculus activity peaked once in spring 2003, and the species was present only in low numbers the rest of the study duration (Fig. 1C). D. onoharaensum experienced a major flight peak in spring and several minor peaks in summer 2003 (Fig. 1E). Xyleborus californicus Wood (Fig. 1F) and X. atratus (Fig. 1I) showed two distinct peaks in activity in the spring of each year. Ambrosiodmus rubricollis (Eichhoff) (Fig. 1G) activity peaked in early May 2003, and it was inconsistently captured during the summer. $X$. impressus (Fig. 1H) had the most irregular flight patterns.

Attack Incidence. Initial destructive sampling revealed 10 X. saxeseni, four X. affinis, two X. crassius- culus, and two $D$. onoharaensum colonizing live $P$. deltoides stems. Significantly more clone ST66 trees suffered beetle attacks than did $\mathrm{S} 7 \mathrm{Cl} 5$ trees $(42.5$ versus $32.8 \%$ respectively; $P=0.0014$; Fisher's exact test). The incidence of attack differed significantly among clone ST66 treatments only, with fertilized trees attacked at the highest rates compared with the other treatments (Fig. 2). No study trees were killed as a result of beetle attacks; however, mortality induced by beetle damage occurred in three trees outside of the study area.

\section{Discussion}

Species Composition. The majority of exotic specimens collected upheld our first hypothesis. The low diversity $(H)$ and evenness $(J)$, second lowest of six studies in this region (Table 3), were because of large captures of $X$. saxeseni and very low captures of several other species.

The predominance of $X$. saxeseni is in agreement with other southeastern U.S. studies (Roling and Kearby 1975, Flechtmann et al. 1999, Hanula et al. 2002; Table 3), including a survey $20 \mathrm{yr}$ earlier in South Carolina peach orchards (Kovach and Gorsuch 1985). $X$. saxeseni attacks numerous species of dead or dying hardwoods and conifers, and is common across the southeastern United States (Drooz 1985). Its ambrosia 


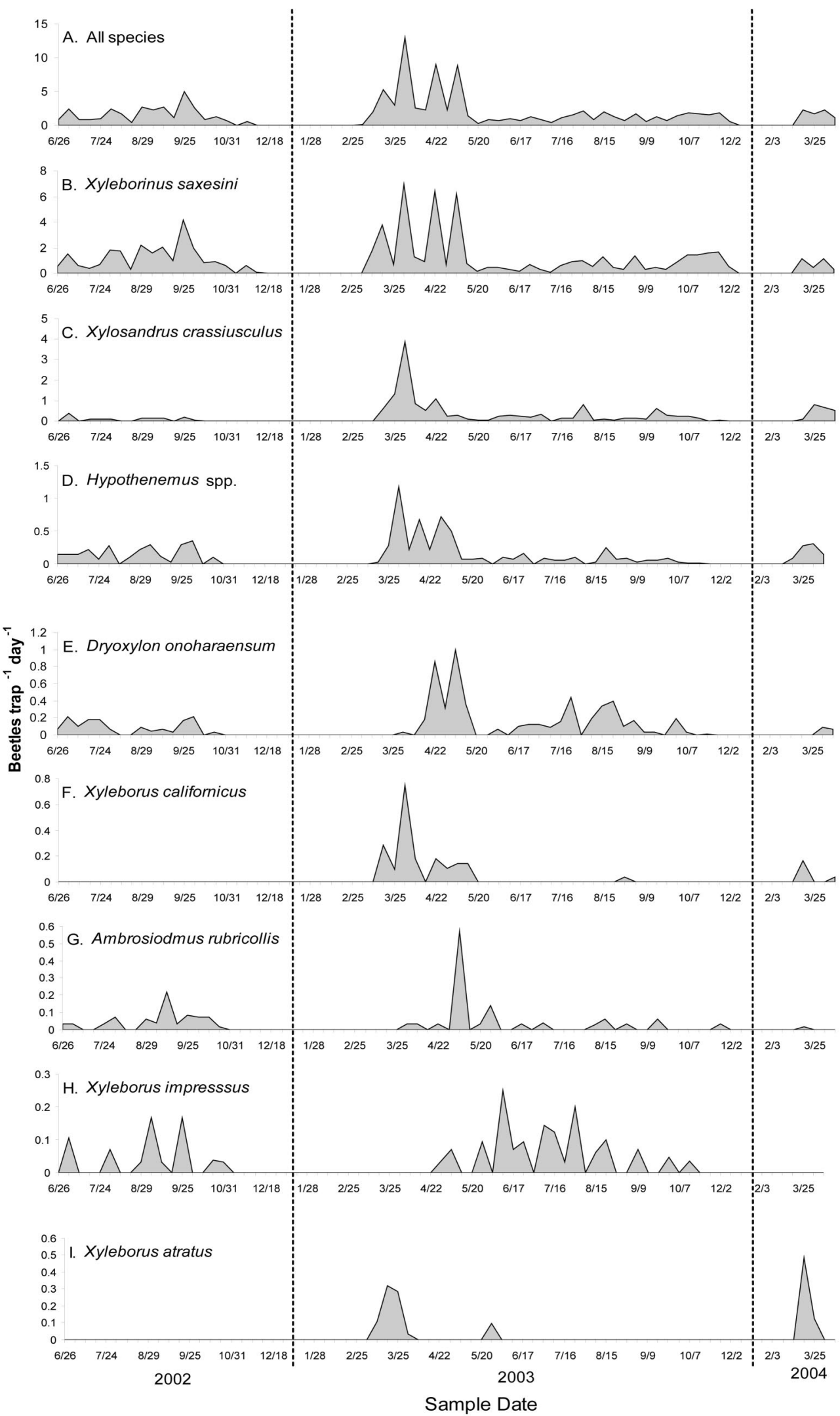

Fig. 1 Seasonal flight patterns of the total (A) and eight most common ambrosia beetles (B-I) captured at the Savannah River site near Aiken, SC, from June 2002 through April 2004. 


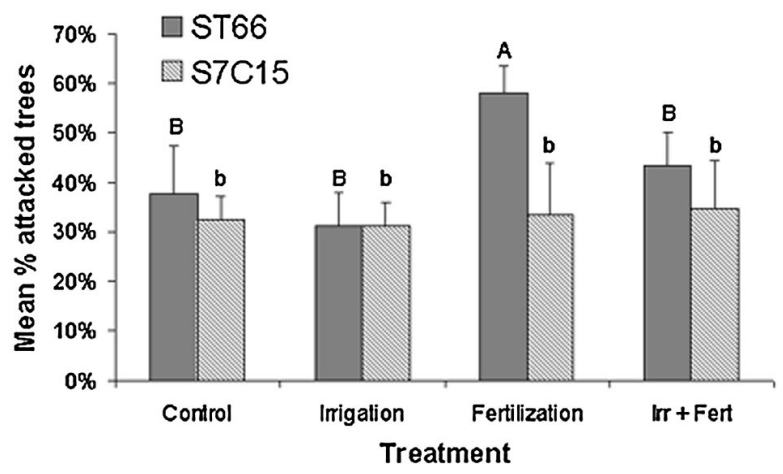

Fig. 2. Ambrosia beetle attack incidence in June 2002 on $P$. deltoides trees receiving various resource amendment treatments. Treatments within a clone sharing a letter are not significantly different $(\alpha=0.05$; Tukey test).

fungus, Ambrosiella sulfurea Batra, is associated with (but has not been shown to cause) the decline of peach trees (Kovach and Gorsuch 1988). We observed fungal staining in destructively harvested trees, but the fungus was neither quantified nor identified.

$X$. crassiusculus was trapped in large numbers by using ethanol-baited traps in this and two other studies (Kovach and Gorsuch 1985, Oliver and Mannion 2001; Table 3) in addition to our study, possibly because these studies also used ethanol lures. Because of its propensity to attack and kill living trees (Atkinson et al. 1988b), which may at times emit ethanol (Kimmerer and Kozlowski 1982) and the apparent expansion of its range to the Pacific Northwest (ODA 1999), $X$. crassiusculus is a potentially serious pest of nursery stock, fruit orchards, and ornamental trees throughout North America (Kovach and Gorsuch 1985, Atkinson et al. 1988b, Mizell et al. 1994, Oliver and Mannion 2001 ). Up to 59 progeny have been shown to emerge from a single gallery (Oliver and Mannion 2001), demonstrating its capacity for population growth.

We captured D. onoharaensum (=Xyleborus onoharaensis) (Bright and Rabaglia 1999) in relatively large numbers compared with other studies in the southeastern United States (Table 3). Little is known regarding this species' biology, but it has now been captured in several southeastern states (Bright and Rabaglia 1999).

X. californicus was first reported in South Carolina in the early 1990s (Vandenberg et al. 2000), and it was caught in 2003 and 2004 (Table 2). We caught $X$. californicus and A. rubricollis in relatively large numbers considering reports of its capture are few (Kovach 1986, Oliver and Mannion 2001, Grant et al. 2003; Table 3). Other species, including Micracisella nanula (LeConte), Pityogenes hopkinsi Swaine, and X. californicus were only captured in one other southeastern U.S. study, and E. validus and X. impressus (recognized as a synonym of $X$. ferrugineus since 1960; Rabaglia 2005) were not reported elsewhere (Table 3 ).

Flight Patterns. Flight patterns, particularly for $X$. saxeseni, observed in our study (a large peak in early spring, and a smaller peak in autumn) agreed relatively well with other reports from the southeastern United States (Roling and Kearby 1975, Turnbow and
Franklin 1980, Kovach 1986, Atkinson et al. 1988a, Weber and McPherson 1991, Oliver and Mannion 2001). We observed a slightly earlier X. crassiusculus flight peak than in Tennessee (Oliver and Mannion 2001), possibly because of weather. The major activity peak in April and May for Hypothenemus spp. flight mirrored that reported by Atkinson et al. (1988a).

Attack Incidence. There is a wide range of susceptibility to pests as well as pest host preference among P. deltoides clones (Coyle et al. 2005). For example, clones in this plantation differed in their susceptibility to T. lobulifera (Coyle 2002). However, no studies have compared ambrosia beetle attack incidence on Populus clones, because attacks on healthy hosts are a relatively new phenomenon (Kühnholz et al. 2001). Clone ST66 was attacked more than clone S7C15 (Fig. 2 ), even though diameter between clones and among treatments was nearly identical (Coyle and Coleman 2005). However, we cannot determine whether this was because of host susceptibility or beetle preference.

The effect of resource amendments such as irrigation and fertilization on tree susceptibility to pests is under debate (Herms and Mattson 1992, Koricheva et al. 1998, Herms 2002, Huberty and Denno 2004). The growth-differentiation balance hypothesis (GDBH) for a resource-based balance between plant growth and defense (Herms and Mattson 1992) best explains the interaction between resource availability and host susceptibility. If resource availability limits growth, increases in resource availability will stimulate plant growth at the expense of defense. Our data suggest that the GDBH may differ among genotypes, because beetle attack incidence did not differ among resource amendment treatments in clone S7C15, yet ST66 trees receiving fertilization were attacked the most. The synthesis of Lorio (1986) of the ecology of the southern pine beetle, Dendroctonus frontalis Zimmermann (Coleoptera: Scolytidae), provides a compelling argument in support of the GDBH for southern pines. Attacks by Scolytidae are greatest in the spring when trees are allocating most of their resources to new growth and not defense. However, bark and ambrosia beetle attack rates dwindle throughout the summer as tree growth levels off and resources are converted into 
defensive compounds (except for an occasional peak in late summer or fall, generally corresponding to a drought period and subsequent tree stress).

White pine weevil, Pissodes strobi (Peck), attack rates on spruce, Picea glauca (Moench) Voss $\times P$. engelmannii Parry ex. Engelmann, also increased as fertilization rates increased (vanAkker et al. 2004). Fertilization increased plant material available for weevil feeding, but it did not affect induced resistance capabilities. With only two irrigation and fertilization treatments, this study was not designed to test the GDBH (Wilkens 1997, Stamp 2004), nor was that its original purpose (Coleman et al. 2004). Although growth losses to weevils were less than gains from fertilization, additional pest management tactics may be required if fertilization is used as a silvicultural treatment.

\section{Acknowledgments}

We thank M. D. Coleman and J. I. Blake (USDA-Forest Service) for project support, M. C. Hall and A. T. Slack (USDA-Forest Service) for technical assistance, and R. J. Rabaglia (Maryland Department of Agriculture) for specimen identification. Reviews by R. J. Rabaglia, J. L. Foltz (University of Florida), A. Sallé (University of WisconsinMadison), J. H. Borden (Phero Tech, Inc.), and one anonymous reviewer greatly improved the quality of this manuscript. Funding was provided by Bartlett Tree Research Laboratories and the U.S. Department of Energy-Savannah River Operations office through the U.S. Forest ServiceSavannah River under Interagency Agreement DE-AI0900SR22188.

\section{References Cited}

Atkinson, T. H., J. L. Foltz, and M. D. Connor. 1988a. Flight patterns of phloem- and wood-boring Coleoptera (Scolytidae, Platypodidae, Curculionidae, Buprestidae, Cerambycidae) in a north Florida slash pine plantation. Environ. Entomol. 17: 259-265.

Atkinson, T. H., J. L. Foltz, and R. C. Wilkinson. 1988b. Xylosandrus crassiusculus (Motschulsky), an Asian ambrosia beetle recently introduced into Florida (Coleoptera: Scolytidae). Fla. Dept. Agric. Consumer Serv. Entomol. Circ. 310.

Bright, D. E., and R. J. Rabaglia. 1999. Dryoxylon, a new genus for Xyleborus onoharaensis Murayama, recently established in the southeastern United States (Coleoptera: Scolytidae). Coleop. Bull. 53: 333-337.

Bright, D. E., and R. E. Skidmore. 1997. A catalog of Scolytidae and Platypodidae (Coleoptera), supplement 1 (1990-1994). NRC Research Press, Ottawa, Ontario, Canada.

Coleman M. D., D. R. Coyle, J. Blake, K. Britton, M. Buford, B. Campbell, J. Cox, B. Cregg, D. Daniels, M. Jacobson, et al. 2004. Production of short rotation woody crops grown with a range of nutrient and water availability: establishment report and first-year responses. U.S. Dep. Agric.-Forest Service, Southern Research Station, Asheville, NC. SRS-GTR-072.

Coyle, D. R. 2002. Effects of clone, silvicultural, and miticide treatments on cottonwood leafcurl mite (Acari: Eriophyidae) damage in plantation Populus. Environ. Entomol. 31: 1000-1008.
Coyle, D. R., and M. D. Coleman. 2005. Forest production responses to irrigation and fertilization are not explained by shifts in allocation. For. Ecol. Manag. 208: 137-152.

Coyle, D. R., T. E. Nebeker, E. R. Hart, and W. J. Mattson, Jr. 2005. Biology and management of insect pests in North American intensively-managed hardwood forest systems. Annu. Rev. Entomol. 50: 1-29.

Dickmann, D. I., and K. W. Stuart. 1983. The Culture of Poplars in Eastern North America. Michigan State University Press, East Lansing, MI.

Drooz, A. T. 1985. Insects of Eastern Forests. Misc. Publ. 1426. U.S. Dep. Agric.-For. Serv., Washington, DC.

Fenning, T. M., and J. Gershenzon. 2002. Where will the wood come from? Plantation forests and the role of biotechnology. Trends Biotechnol. 20: 291-296.

Flechtmann, C.A.H., M. J. Dalusky, and C. W. Berisford. 1999. Bark and ambrosia beetle (Coleoptera: Scolytidae) responses to volatiles from aging loblolly pine billets. Environ. Entomol. 28: 638-648.

Grant, J. F., A. J. Jayor, P. I. Lambdin, and G. J. Wiggins. 2003. New species records and incidence of bark beetles and ambrosia beetles (Coleoptera: Scolytidae) from the barrens of middle Tennessee, USA. Nat. Areas J. 23: 278 283.

Haack, R. A. 2001. Intercepted Scolytidae (Coleoptera) at U.S. ports of entry: 1985-2000. Integr. Pest Manag. Rev. 6: 253-282.

Hanula, J. L., J. R. Meeker, D. R. Miller, and E. L. Barnard. 2002. Association of wildfire with tree health and numbers of pine bark beetles, reproduction weevils and their associates in Florida. For. Ecol. Manag. 170: 233-247.

Herms, D. A. 2002. Effects of fertilization on insect resistance of woody ornamental plants: reassessing an entrenched paradigm. Environ. Entomol. 31: 923-933.

Herms, D. A., and W. J. Mattson. 1992. The dilemma of plants: to grow or defend. Q. Rev. Biol. 67: 283-335.

Huberty, A. F., and R. F. Denno. 2004. Plant water stress and its consequences for herbivorous insects: a new synthesis. Ecology 85: 1383-1398.

Humble, L. M. 2003. Invasive bark and wood-boring beetles in British Columbia, Canada. pp. 69-77 In R. I. Alfaro, K. Day, S. Salom, K.S.S. Nair, H. Evans, A. Leibhold, F. Lieutier, M. Wagner, K. Futai, and K. Suzuki [eds.], Protection of world forests from insect pests: advances in research. International Union of Forest Research Organization, World Series 11, Vienna, Austria.

Kimmerer, T. W., and T. T. Kozlowski. 1982. Ethylene, ethane, acetaldehyde, and ethanol production by plants under stress. Plant Physiol. 69: 840-847.

Koricheva, J., S. Larsson, and E. Haukioja. 1998. Insect performance on experimentally stressed plants: a meta-analysis. Annu. Rev. Entomol. 43: 195-216.

Kovach, J. 1986. Life cycle, seasonal distribution, and tree responses to scolytid beetles in South Carolina peach orchards. Ph.D. dissertation, Clemson University, Clemson, SC.

Kovach, J., and C. S. Gorsuch. 1985. Survey of ambrosia beetle species infesting South Carolina peach orchards and a taxonomic key for the most common species. J. Agric. Entomol. 2: 238-247.

Kovach, J., and C. S. Gorsuch. 1988. Response of young peach trees to Ambrosiella sulphurea, a symbiotic fungus of Xyleborinus saxeseni. Plant Dis. 72: 225-227.

Kühnholz, S., J. H. Borden, and A. Uzunovic. 2001. Secondary ambrosia beetles in apparently healthy trees: adaptations, potential causes and suggested research. Integr. Pest Manag. Rev. 6: 209-219. 
Liebhold, A. M., W. L. MacDonald, D. Bergdahl, and V. C. Mastro. 1995. Invasion by exotic forest pests: a threat to forest ecosystems. For. Sci. Monogr. 30: 1-49.

Lindgren, B. S. 1983. A multiple funnel trap for scolytid beetles (Coleoptera). Can. Entomol. 115: 299-302.

Lorio, P. L.,Jr. 1986. Growth-differentiation balance: a basis for understanding southern pine beetle-tree interactions. For. Ecol. Manag. 14: 259-273.

Mattson, W. J., P. Niemela, I. Millers, and Y. Inguanzo. 1994. Immigrant phytophagous insects on woody plants in the United States and Canada: an annotated list. U.S. Dep. Agric.-Forest Service North Central Forest Experiment Station, St. Paul, MN. Gen. Tech. Rep. NC-169.

McLean, J. A. 1985. Ambrosia beetles: a multimillion dollar degrade problem of sawlogs in coastal British Columbia. For. Chron. 61: 295-298.

Mizell, R., S. K., Braman, B. Sparks, and W. Hudson. 1994. Outbreak of the Asian ambrosia beetle, Xylosandrus crassiusculus (Motschulsky), is cause for concern, pp. 191193. In B. L. James [ed.], Proceedings 39th Annual Southern Nurserymen's Association Research Report. Southern Nurserymen's Association, Marietta, GA.

Oliver, J. B., and C. M. Mannion. 2001. Ambrosia beetle (Coleoptera: Scolytidae) species attacking chestnut and captured in ethanol-baited traps in middle Tennessee. Environ. Entomol. 30: 909-918.

Orbay, L., J. A. McLean, B. J. Sauder, and P. L. Cottell. 1994. Economic losses resulting from ambrosia beetle infestations of sawlogs in coastal British Columbia, Canada. Can. J. For. Res. 24: 1266-1276.

[ODA] Oregon Department of Agriculture. 1999. Plant Division annual report. Oregon Department of Agriculture, Salem, OR.

Pielou, E. C. 1966. The measurement of diversity in different types of biological collections. J. Theor. Biol. 13: 131-144.

Pimentel, D., L. Lach, R. Zuniga, and D. Morrison. 2000. Environmental and economic costs of non-indigenous species in the United States. Bioscience 50: 53-65.

Rabaglia, R. J. 2005. The validity of Xyleborus impressus Eichhoff (Coleoptera: Curculionidae: Scolytinae) as distinct from Xyleborus ferrugineus (Fabricius). Coleop. Bull. 59: 261-266.

Roling, M. P., and W. H. Kearby. 1975. Seasonal flight and vertical distribution of Scolytidae attracted to ethanol in an oak-hickory forest in Missouri. Can. Entomol. 107: 1315-1320.

Rudinsky, J. A. 1962. Ecology of Scolytidae. Annu. Rev. Entomol. 7: 327-348.

Schiefer, T. L., and D. E. Bright. 2004. Xylosandrus mutilatus (Blandford), an exotic ambrosia beetle (Coleoptera:
Curculionidae: Scolytinae: Xyleborini) new to North America. Coleop. Bull. 58: 431-438.

Shannon, C. E. 1948. A mathematical theory of communication. Bell System Tech. J. 27: 379-423, 623-656.

Simberloff, D., I. M. Parker, and P. N. Windle. 2005. Introduced species policy, management, and future research needs. Front. Ecol. Environ. 3: 12-20.

Stamp, N. 2004. Can the growth-differentiation balance hypothesis be tested rigorously?. Oikos 107: 439-448.

Stanton, B., J. Eaton, J. Johnson, D. Rice, B. Schuette, and B. Moser. 2002. Hybrid poplar in the Pacific Northwest. J. For. 100: 28-33.

Stanturf, J. A., C. van Oosten, D. A. Netzer, M. D. Coleman, and C. J. Portwood. 2001. Ecology and silviculture of poplar plantations, pp. 153-206. In D. I. Dickmann, J. G. Isebrands, J. E. Eckenwalder, and J. Richardson [eds.], Poplar Culture in North America. National Research Council, Ottawa, Canada.

Turnbow, R. H., and R. T. Franklin. 1980. Flight activity by Scolytidae (Coleoptera) in the northeast Georgia piedmont. J. Ga. Entomol. Soc. 15: 26-37.

vanAkker, L., R. I. Alfaro, and R. Brockley. 2004. Effects of fertilization on resin canal defences and incidence of Pissodes strobi attack in interior spruce. Can. J. For. Res. 34: 855-862.

Vandenberg, N. V., R. J. Rabaglia, and D. E. Bright. 2000. New records of two Xyleborus (Coleoptera: Scolytidae) in North America. Proc. Entomol. Soc. Wash. 102: 62-68.

Weber, B. C., and J. E. McPherson. 1991. Seasonal flight patterns of Scolytidae (Coleoptera) in black walnut plantations in North Carolina and Illinois. Coleop. Bull. 45: $45-56$.

Wilcove, D. S., D. Rothstein, J. Dubow, A. Phillips, and E. Losos. 1998. Quantifying threats to imperiled species in the United States. Bioscience 48: 607-615.

Wilkens, R. T. 1997. Limitations of evaluating the growthdifferentiation balance hypothesis with only two levels of light and water. Ecoscience 4: 319-326.

Wood, S. L. 1982a. The bark and ambrosia beetles of North and Central America (Coleoptera: Scolytidae), a taxonomic monograph. Great Basin Nat. Mem. 6: 1-1359.

Wood, S. L. 1982b. The role of pheromones, kairomones, and allomones in the host selection and colonization behavior of bark beetles. Annu. Rev. Entomol. 27: 411446.

Wood, S. L., and D. E. Bright. 1992. A catalog of Scolytidae and Platypodidae (Coleoptera), Part 2: taxonomic index. Great Basin Nat. Mem. 13: 1-1553.

Zar, J. H. 1999. Biostatistical Analysis, 4th ed. Prentice Hall, Upper Saddle River, NJ.

Received 3 March 2005; accepted 23 August 2005. 